the complaints of US car manufacturers to the World Trade Organization (WTO)?

The question must be asked because it has already arisen, if in a different context. The WTO is the inheritor of the General Agreement on Tariffs and Trade (GATT), within which framework the principal trading nation had been negotiating a complicated package of measures aimed at further liberalization of the trading regime. One component of that negotiation was the notion that international trade in services should be liberalized, in the sense that companies offering potential customers services as different as computer management and life insurance should be free to offer them internationally, within the company of the countries signing on to a negotiated arrangement. The completion of that arrangement was delegated to WTO.

Superficially, at least, the United States is again the chief source of trouble. From services in general, the scope of the present negotiations has been narrowed to include only financial services - banking, insurance and the marketing of financial securities such as stocks and bonds. But the precedents set in these negotiations will no doubt apply to the more technical issues that come later on the agenda, telecommunications in particular. The difficulty is that the spirit of the GATT (and WTO) rules does not prevent countries from keeping overseas companies out of their domestic markets, which they may do by means of tariffs, but do require that they do not discriminate between overseas suppliers on the grounds of nationality.

That implies that country A may decide to open its domestic market for some commodity or service to all comers, and then find that country B is less liberal by imposing a (non-discriminatory) tariff on imported goods or by imposing impossibly tough conditions on those who would sell services. The underlying principle is that these asymmetries will not matter in the long run. Consumers in country $A$ will benefit immediately from competition between a diversity of suppliers, domestic as well as foreign, while consumers in country B will eventually come to envy the benefits people elsewhere enjoy, and will make their government change its policy. The benefit accruing to those who live in country $A$ is not, of course, to a first approximation, diminished by the policy of country B, however illiberal it may be.

What has now happened at the WTO is that the United States is insisting that it will discriminate against others wishing to sell it financial services who fail to offer the same liberality as it offers to others. Japanese banks will be free to operate in the United States only if US banks can set up in Tokyo, for example. On the face of things, this looks fair. And it is inevitable that the WTO pact on financial services will not be signed unless the 30 negotiating countries are satisfied with what their potential partners offer. But to go so far as to insist that all trading partners should offer exactly the same liberal package is to ask more than is necessary. It is also an awkward echo of the automobile dispute. For the past quarter of a century, the United States has been the chief force impelling the world towards free trade, mostly by its support for international institutions. It is not easy to understand why its enthusiasm seems to have evaporated $\square$

\section{A broken embargo}

Journalists who break agreed embargoes damage not only themselves but also their profession.

THIS journal follows many (but not all) others in operating a strict policy on the release of information about to be published. As authors know well enough, they are told when a manuscript is accepted for publication that they should not make the information public until the day and even the hour of publication. Part of the explanation of that policy is that Nature does not wish its own readers to be scooped by advance publicity for an important development. And much of what passes for important news is not readily digested by busy journalists, for which reason Nature distributes each week a readable press digest, again with a strict embargo linked with the date of publication. If they wish, journalists can be sent an advance copy of an article in which they are particularly interested. The service appears to be welcomed by journalists, who seem to find it helpful.

It goes without saying that this practice is not meant to prevent researchers saying what they wish at scientific meetings. The rule is that if they give an account of their most recent work and happen to be heard by a journalist, they have a duty of courtesy to him or her to answer intelligent questions after their presentation, whether or not the person concerned is planning to write something about the new development. But researchers with an article in the press should stop short of handing over a copy of the proofs or of being filmed for a television programme without a firm assurance than the embargo will be respected. That, too, seems to be accepted by journalists and researchers alike.

Except, it appears, for Mr Tim Friend, a journalist with the daily USA Today. One of highlights of last week's issue of Nature was the article by R. Sherrington et al. describing mutations in a gene apparently responsible for some earlyonset Alzheimer's disease (Nature 375, 754-760; 1995). On Tuesday last week, one of the authors was giving evidence to a US congressional committee seeking opinions on the importance of basic research, and offered the characterization of this gene as one of the benefits. The reference was picked up by ABC News and eventually mentioned in the television network's 7 p.m. news bulletin. No less a person than Mr Peter Jennings referred to the discovery and its impending publication, adding that the authors had nothing more to say at that stage.

Unconstrained, USA Today published a full account of the research the following day. Friend quoted Jennings as the excuse for this deliberate breaking of an agreed embargo, saying that the fault lay with Jennings and not with him. In this journal's view, that is disingenuous. Indeed, Jennings as the author had said no more than had the panel on Nature's contents page the previous week. Nature therefore has no choice but to remove Friend and USA Today from its press distribution list. While it may seem to them that they are being penalized unfairly for breaking bureaucratic rules, their real disservice is to their fellow-journalists. 